\title{
Maps, Figures, and Illustrations
}

MAPS

I. Ghent in the fourteenth century

2. Flanders in the fourteenth century

FIGURES

I. The governance of Ghent during the fourteenth century 4

2. Genealogy of the van Artevelde family 73

3. Genealogy of the de Mey and van Merlaer families 84

\section{ILLUSTRATIONS}

I. The Kalandenberg in Ghent, as shown on the anonymous plan of the city, I 534

2. Salary payment to James van Artevelde and the other four captains, 3 January I 338

3. The chronicler Jean Froissart

4. Record of atonement for the murder of James van

Artevelde the younger, I 373

5. The grain staple at Ghent 
6. Delegation from Ghent negotiates with Count Louis of Male, I38I

I 2 I

7. Civil war in Ghent

I 26

8. The Battle of Westrozebeke, 27 November I 382

I 86 